\title{
Peran Brand Ambassador Pada Iklan Dalam Membangun Brand Awareness (Studi Kasus Iklan Youtube LG G7 Thinq BTS)
}

\author{
Vionita Budiman, Riris Loisa, Nigar Pandrianto \\ vionita.915150044@stu.untar.ac.id,ririsl@fikom.untar.ac.id,nigarp@fikom.untar.ac.id \\ Fakultas Ilmu Komunikasi Universitas Tarumanagara
}

\begin{abstract}
One of the marketing communication strategy that used by some company to attract the attention of the target audience, is by using a brand ambassador in an advertisement. This research to discuss regarding the role of BTS as the brand ambassador in Youtube advertisements in building awareness. With their achievements and their massive popularity, Korean boygroup, Bangtan Sonyeondan or BTS trusted and chosen as brand ambassador of $L G G 7$ ThinQ to expect to be able create new image for smartphone $L G G 7$ Thin $Q$ in global market. The use of BTS as the brand ambassador expected to raise brand awareness in mind of target audience. For a brand ambassador selection, there are attributes that must be considered, as a match between profession of that brand ambassador with the brand, skill of the brand ambassador itself. The concept that used in this research was internet advertisement, brand ambassador and brand awareness. The type of this research is descriptive-qualitative. This research uses case study method. The conclusion of this research indicated that BTS as brand ambassador of LG G7 ThinQ has a match and has skill play a role in building brand awareness of $L G$ for BTS's fans.
\end{abstract}

Keywords : Internet Advertisement, Brand Ambassador, Brand Awareness.

\section{Abstrak}

Salah satu strategi komunikasi pemasaran yang dilakukan oleh beberapa perusahaan untuk menarik perhatian target audience, adalah dengan menggunakan brand ambassador dalam iklan. Penelitian ini membahas mengenai peran BTS sebagai brand ambassador pada iklan Youtube dalam membangun brand awareness. Dengan banyaknya prestasi dan kepopulerannya yang mendunia, boygroup asal Korea Selatan, Bangtan Sonyeondan atau yang lebih dikenal dengan nama BTS dipercaya sebagai brand ambassador LG G7 ThinQ dengan harapan mampu menciptakan image baru bagi smartphone LG G7 ThinQ di pasar global. Penggunaan BTS sebagai brand ambassador diharapkan juga dapat membangun kesadaran merek dalam benak target audience. Dalam pemilihan brand ambassador tentunya terdapat atribut yang harus diperhatikan, seperti kecocokan antara profesi brand ambassador dengan brand itu, keahlian dari si brand ambassador itu sendiri. Konsep yang digunakan dalam penelitian ini adalah iklan internet, brand ambassador dan brand awareness. Jenis penelitian ini adalah penelitian dengan metode kualitatif deskriptif. Penelitian ini menggunakan metode penelitian studi kasus. Kesimpulan dalam penelitian ini menunjukkan bahwa BTS memiliki kecocokan dan memiliki keahlian sebagai brand ambassador dan berperan dalam membangun kesadaran merek LG pada benak para penggemar BTS.

Kata Kunci : Iklan Internet, Brand Ambassador, Brand Awareness 


\section{Pendahuluan}

Di era modern seperti saat ini, teknologi menjadi semakin maju dan canggih, baik pada bidang komunikasi maupun informasi. Kemajuan teknologi ini ditandai dengan kemunculannya internet. Dengan munculnya internet, informasi menjadi mudah tersebar secara cepat dan luas sehingga masyarakat Indonesia bisa dengan mudahnya mengakses dan mendapatkan informasi dari berbagai negara lain. Dengan demikian, hal ini mendorong budaya luar untuk masuk ke Indonesia.

Beberapa budaya dari luar, seperti budaya Amerika, China, bahkan budaya Korea Selatan pun sudah masuk ke Indonesia. Dengan berkembangnya budaya Korea Selatan sendiri mampu mempengaruhi pilihan masyarakat terhadap produk buatan Korea Selatan, mulai dari kosmetik, smartphone, barang elektronik, kendaraan, fashion, makanan serta lifestyle (gaya hidup).

Gaya hidup masyarakat Indonesia pun mulai berubah seiring dengan kemajuan teknologi yang sangat berpengaruh dalam kehidupan manusia. Teknologi yang telah dan terus berkembang pesat hingga saat ini, memudahkan manusia untuk melakukan aktivitas kesehariannya dalam berbagai bidang, terutama dalam bidang komunikasi.

Smartphone telah menjadi salah satu kebutuhan dasar untuk melakukan komunikasi di era modern ini, sehingga menciptakan peluang yang besar bagi perusahaan-perusahaan smartphone. Perusahaan-perusahaan smartphone bersaing satu sama lain untuk menarik perhatian dan menguasai pangsa pasar. Maka dari itu perusahaan terus menciptakan strategi untuk mampu bertahan. Dibutuhkannya beberapa strategi yang yang tepat untuk menarik perhatian masyarakat dan menanamkan dalam benak konsumen. Salah satunya adalah dengan menggunakan brand ambassador. Penggunaan brand ambassador juga diharapkan guna membangun kesadaran merek suatu produk yang diwakilkan celebrity yang bersangkutan agar dapat mengakar kuat di benak masyarakat.

Menurut Lea-Greenwood dalam Putra, Suharyono, Abdillah (2014) Brand Ambassador adalah alat yang digunakan oleh perusahaan untuk mengkomunikasikan dan menghubungkannya dengan publik, dengan harapan mereka dapat meningkatkan penjualan. Penggunaan brand ambassador dilakukan oleh perusahaan dengan harapan memberikan dampak yang positif bagi perusahaan. Brand ambassador biasanya dipilih berdasarkan pencitraan melalui seorang selebrititas yang terkenal.

Salah satu perusahaan smartphone asal Korea Selatan yang terkenal di seluruh penjuru dunia termasuk di Indonesia adalah LG. Produk-produk LG mungkin sudah tidak asing lagi di mata masyarakat Indonesia. Produk-produk LG mulai dari smartphone, Televisi, Kulkas, Air Conditioner (AC) pun juga sudah banyak digunakan oleh masyarakat Indonesia.

Pada produk smartphone terbaru LG, Bangtan Boys atau biasa dikenal dengan sebutan BTS terpilih menjadi brand ambassador produk LG G7 ThinQ. BTS (Hangul: 방탄소년단; RR: Bangtan Sonyeondan) adalah boygroup asal Korea Selatan yang dibentuk oleh Big Hit Entertainment pada 13 Juni 2013. Dengan banyaknya prestasi dan kepopulerannya yang mendunia, BTS merupakan grup KPop pertama yang memenangkan "Top Social Artist" dalam Billboard Music Awards dipercaya sebagai endorser LG G7 ThinQ dengan harapan mampu menciptakan image baru bagi smartphone LG G7 ThinQ di pasar global. (Sumber: https://www.lg.com/ph/press-release/lg-signs-international-k-pop-sensation-bts-asglobal-mobile-ambassadors, diakses pada tanggal 20 September 2018) 
Menurut Aaker (Priansa, 2017: 254), brand awareness adalah berkaitan dengan kemampuan konsumen untuk mengenali atau mengingat kembali suatu merek merupakan bagian dari kategori produk tertentu. Penggunaan BTS sebagai brand ambassador LG diharapkan mampu membangun brand awareness LG dan menciptakan citra positif mengingat jumlah penggemar BTS yang tidak sedikit di seluruh penjuru dunia termasuk di Indonesia.

Periklanan merupakan salah satu bentuk komunikasi yang digunakan sebagai alat pemasaran. Saat ini banyak perusahaan yang menggunakan internet sebagai salah satu media komunikasi pemasaran untuk menyampaikan pesan kepada khalayak karena media internet bersifat luas, biaya yang relatif murah dan mudah untuk digunakan. Perusahaan menggunakan internet sebagai media periklanan untuk menyebarkan informasi dan menciptakan kesadaran merek di benak khalayak. Youtube merupakan salah satu salah website yang paling sering diakses oleh para pengguna internet karena Youtube menampilkan informasi dalam bentuk video. Sehingga Youtube dimanfaatkan oleh beberapa perusahaan untuk menampilkan iklan produk mereka ketika pengguna internet akan melihat video yang akan mereka tonton.

Berdasarkan uraian latar belakang dan pembahasan diatas, penulis tertarik untuk meneliti lebih jauh mengenai peran brand ambassador dalam membangun brand awareness untuk mencari bagaimana peran brand ambassador dalam membangun brand awareness? Tujuan dilakukannya penelitian ini adalah untuk mengetahui dan menganalisis peran brand ambassador 'BTS' dalam membangun brand awareness LG pada audience serta untuk mengetahui tanggapan audience yang berupa penggemar BTS mengenai BTS sebagai brand ambassador dalam membangun brand awareness LG.

\section{Metode Penelitian}

Jenis penelitian yang digunakan dalam penilitian penulis adalah jenis penelitian kualitatif. Menurut Moleong (2012:6), penelitian kualitatif adalah penelitian yang dilakukan dengan tujuan memahami fenomena apa yang dialami oleh subjek penelitian seperti tentang perilaku, persepsi, motivasi serta tindakan secara holistik dan dengan menggunakan cara deskripsi dalam bentuk berupa kata-kata dan bahasa, pada suatu konteks khusus yang alamiah dengan menggunakan berbagai metode ilmiah. Sedangkan menurut Bodgan dan Taylor dalam Basrowi dan Suwandi (2008:21), penelitian kualitatif merupakan penelitian yang menghasilkan data dalam bentuk deskriptif berupa kata-kata tertulis maupun lisan dan perilaku dari orangorang yang diamatinya.

Dalam penelitian yang diteliti oleh penulis, penulis menggunakan jenis penelitian kualitatif deskriptif karena penulis ingin mendapatkan hasil data perihal peran celebrity endorser dalam membangun brand awareness secara terperinci dan mendalam. Penelitian deskriptif kualitatif bertujuan untuk menggambarkan, meringkaskan berbagai kondisi atau fenomena realitas sosial yang ada di masyarakat menjadi objek penelitian, dan berupaya menarik realitas ke permukaan sebagai suatu ciri, karakter, model atau gambaran tentang suatu kondisi atau fenomena tertentu (Bungin, 2010:68).

Metode penelitian yang digunakan oleh penulis dalam penelitian ini adalah metode studi kasus. Menurut Maxfield dalam Nazir (2011:57), studi kasus adalah penelitian tentang status subjek penelitian yang berkenan dengan suatu fase spesifik 
atau khas dari keseluruhan personalitas. Umumnya dalam metode studi kasus, subjek penelitiannya meliputi individu, kelompok, lembaga maupun masyarakat.

Penulis melakukan pengumpulan data untuk mengumpulkan data dan informasi yang diperlukan dalam penelitian ini, yaitu dengan melakukan wawancara mendalam, melakukan observasi, studi kepustakaan dan melakukan penelusuran data online. Subjek dalam penelitian ini merupakan para penggemar BTS dan objek dalam penelitian ini merupakan brand ambassador BTS dan brand awareness.

Dalam penelitian ini, penulis melakukan analisa data dengan menggunakan model analisis data yang dikemukakan oleh Strauss dan Corbin. Menurut Strauss dan Corbin dalam Emzir (2012:137), analisis data kualitatif, terdiri atas tiga jenis pengodean (coding), yaitu pengodean terbuka (open coding), pengodean berporos (axial coding), dan pengodean selektif (selective coding).

Penulis menggunakan triangulasi dengan sumber data dan triangulasi dengan metode sebagai teknik untuk menguji keabsahan data yang telah didapatkan,

\section{Hasil Temuan dan Diskusi}

Penulis melakukan analisa pada dua iklan LG G7 ThinQ yang diunggah di Youtube, iklan LG G7 ThinQ yang menanmpilkan feature produk yang sama, dengan perbedaan satu dibintangi oleh BTS dan iklan LG G\&7 ThinQ yang tanpa BTS. Berikut ini hasil analisa yang dilakukan oleh penulis.

Iklan 1 merupakan iklan dari LG G7 ThinQ yang menggunakan brand ambassador pada iklan tersebut. Iklan yang berjudul "LG x BTS: Boombox Speaker - LG G7 ThinQ ${ }^{\mathrm{TM}} \mid$ LG USA - RM (Original Cut)" diunggah pada tanggal 30 Mei 2018 telah ditonton sebanyak 2,169,247 kali, dikomentari sebanyak 78 komentar, disukai oleh 1,126 orang dan tidak disukai oleh 11 orang.

Tabel 1. Persentase komentar iklan LG x BTS: Boombox Speaker - LG G7

\begin{tabular}{lll}
\multicolumn{3}{c}{ ThinQ $^{\mathrm{TM}} \mid$ LG USA - RM (Original Cut) } \\
\hline & Jumlah Komentar & Persentase \\
\hline Tentang BTS & 61 komentar & $78,21 \%$ \\
Tertarik dengan LG karena BTS & 10 komentar & $12,82 \%$ \\
Hal lain & 7 komentar & $8,97 \%$ \\
Jumlah keseluruhan & 78 komentar & $100 \%$ \\
\hline
\end{tabular}

Gambar 1. Iklan LG x BTS: Boombox Speaker - LG G7 ThinQ ${ }^{\mathrm{TM}} \mid$ LG USA - RM (Original Cut)

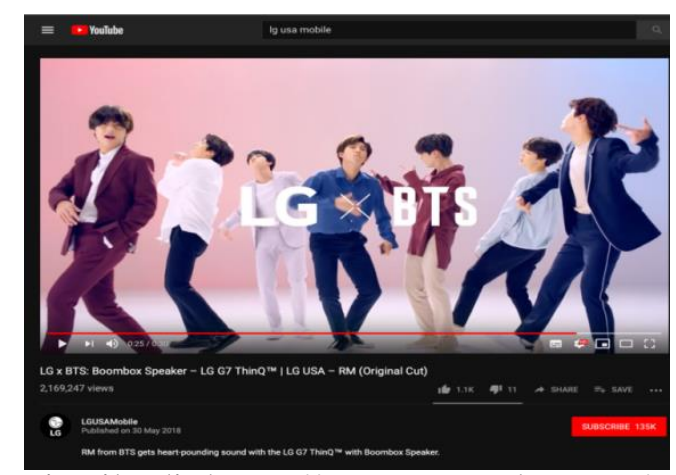

(Sumber: Dokumentasi pribadi, https://www.youtube.com/watch?v=91qnv-fdkUU) 
Iklan 2 merupakan iklan dari LG G7 ThinQ yang tidak menggunakan brand ambassador pada iklan tersebut, hanya menampilkan feature dari smartphone tersebut. Iklan yang berjudul "LG G7 ThinQ ${ }^{\mathrm{TM}}$ - Boombox Speaker" diunggah pada tanggal ..

Tabel 2. Persentase komentar iklan LG G7 ThinQ ${ }^{\mathrm{TM}}$ - Boombox Speaker

\begin{tabular}{lll}
\hline & Jumlah Komentar & Persentase \\
\hline Tentang LG & 2 komentar & $40 \%$ \\
Tertarik dengan LG karena BTS & 1 komentar & $20 \%$ \\
Hal lain & 2 komentar & $40 \%$ \\
Jumlah & 5 komentar & $100 \%$ \\
\hline
\end{tabular}

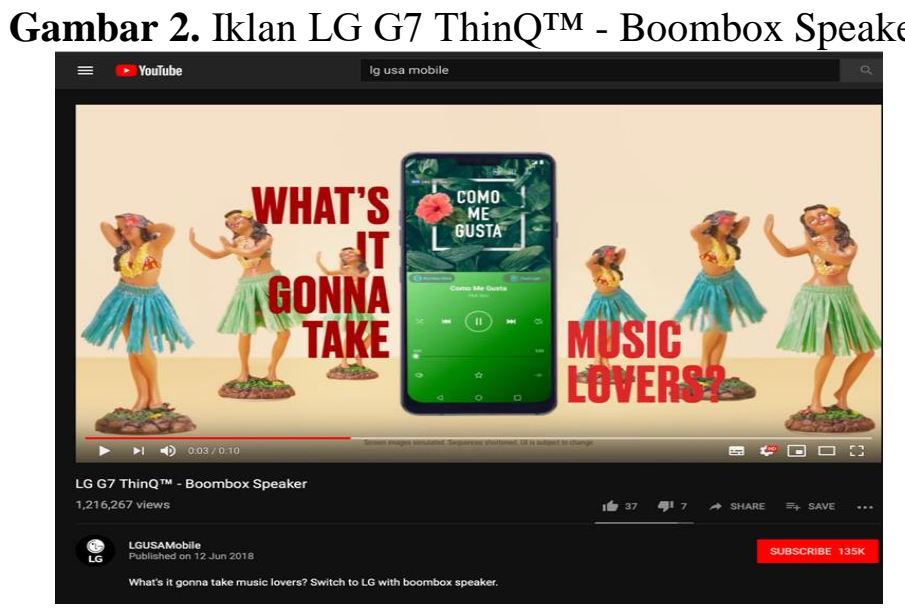

(Sumber: Dokumentasi pribadi, https://www.youtube.com/watch?v=NINT8QhWwU)

Tidak hanya melakukan analisa pada video Youtube, penulis juga mengumpulkan data melalui wawancara dengan beberapa informan berupa para penggemar BTS, yaitu ARMY. Maka pada bagian ini penulis akan menjabarkan hasil temuan dari wawancara dengan menggunakan beberapa konsep dasar yang menjadi acuan penulis dalam menanyakan pertanyaan kepada informan. a. Iklan LG G7 ThinQ di Youtube

Saat ini banyak perusahaan yang menggunakan internet sebagai salah satu media promosi untuk menyampaikan pesan kepada khalayak karena media internet ini bersifat luas, biaya relatif murah dan mudah untuk digunakan. Tujuan perusahaan menggunakan internet sebagai media promosi adalah untuk menyebarkan informasi, menciptakan kesadaran, hingga menciptakan persepsi. (Morissan, 2010:322)

Salah satu perusahaan yang menggunakan internet sebagai media komunikasi pemasaran adalah LG Mobile. LG Mobile menggunakan Yotube sebagai media komunikasi pemasarannya. Menurut dari beberapa penggemar BTS ini mengatakan bahwa mereka mengetahui iklan Youtube LG G7 ThinQ BTS dan iklan ini menarik perhatian mereka.

Dan hal yang menarik dari iklan LG G7 ThinQ menurut enam dari tujuh penggemar, mengatakan bahwa hal yang menarik dari iklan itu adalah brand ambassador nya sendiri, yaitu BTS. Sedangkan satu dari tujuh penggemar 
mengatakan bahwa yang menarik dari iklan itu adalah jingle iklan yang merupakan lagu dari BTS itu sendiri.

Jika dilihat dari hasil analisa kedua video iklan LG G7 ThinQ di Youtube, dapat dilihat perbandingan jumlah ditonton, terlihat jelas bahwa iklan LG G7 ThinQ yang dibintangi oleh brand ambassador lebih banyak mendapatkan banyak respon (seperti jumlah ditonton, jumlah disukai dan jumlah komentar) dibandingkan dengan iklan LG G7 ThinQ yang tanpa dibintangi oleh brand ambassador. Pada iklan LG G7 ThinQ yang berjudul "LG G7 ThinQ ${ }^{\mathrm{TM}}$-Boombox Speaker" tanpa dibintangi oleh BTS pun ada yang berkomentar bahwa mendukung LG karena BTS mengiklankan brand LG.

b. BTS sebagai Brand Ambassador

Menurut Lea-Greenwood (2012:88) dalam Putra, Suharyono, Abdillah (2014), Brand Ambassador adalah alat yang digunakan oleh perusahaan untuk mengkomunikasikan dan menghubungkannya dengan publik, dengan harapan dapat meningkatkan penjualan. Penggunaan brand ambassador dilakukan oleh perusahaan dengan harapan memberikan dampak yang baik bagi perusahaan. Brand ambassador umumnya dipilih berdasarkan pencitraan melalui seorang selebrititas yang terkenal.

Sesuai dengan hasil observasi berita online yang dilakukan oleh penulis mengenai pemberitaan BTS sebagai brand ambassador yang memiliki popularitas yang mendunia dan tidak dapat diragukan lagi. Dilansir Tribunnews dari Allkpop, RM dan kawan-kawan berhasil meningkatkan popularitas serta ketertarikan publik terhadap LG Electronics. Dengan penggunaan BTS sebagai brand ambassador ini membuat LG mengalami banyak peningkatan. Popularitas juga merupakan salah satu hal yang dapat dipertimbangkan dalam memilih brand ambassador. Selain popularitas, terdapat lima atribut yang harus dimiliki oleh brand ambassador, yaitu transference, congruence, kredibilitas, daya tarik, dan power. Tetapi dalam penelitian ini hanya tiga dari lima atribut yang diteliti oleh penulis, yaitu kecocokan BTS sebagai brand ambassador, kredibilitas brand ambassador dan karisma brand ambassador.

BTS sebagai brand ambassador merupakan pilihan yang tepat karena menarik perhatian khususnya bagi para penggemar BTS. Kecocokan BTS sebagai brand ambassador juga didukung oleh pernyataan yang disampaikan oleh pihak LG melalui beberapa pemberitaan yang mengatakan bahwa kualitas yang ada pada BTS cocok dengan merek smartphone LG dan berharap LG bisa menyampaikan kepada pasar global bahwa perangkat seluler LG juga mampu memberikan inovasi yang berani dengan cara yang unik.

Indikator kedua adalah kredibilitas, yaitu dimana konsumen melihat brand ambassador memiliki pengetahuan, keahlian atau pengalaman yang baik, dan kemampuan brand ambassador tersebut dapat dipercaya untuk memberikan informasi yang objektif. Dari hasil wawancara dengan beberapa penggemar yang diwawancarai oleh penulis, dapat dikatakan bahwa BTS memiliki kredibilitas yang baik, karena mampu menyampaikan informasi dengan baik dan mampu meyakinkan penggemarnya mengenai produk LG G7 ThinQ ini.

Dan yang terakhir adalah power, karisma yang dipancarkan oleh brand ambassador sehingga mampu mempengaruhi konsumen untuk membeli maupun menggunakan produk. Beberapa dari penggemar setuju dan mengatakan bahwa BTS memiliki karisma yang mampu mempengaruhi konsumen untuk membeli dan menggunakan produk tersebut. Tetapi beberapa dari penggemar BTS mengatakan 
bahwa BTS memiliki karisma, tetapi masih belum bisa untuk meyakinkan dirinya untuk membeli LG G7 ThinQ ini.

Dan dari hasil pengumpulan data melalui observasi pemberitaan online, dilansir dari wowkeren.com, dengan menggunakan BTS sendiri memberikan respons yang positif baik bagi LG, dimana banyak orang yang tertarik sehingga meningkatkan popularitas brand LG. Sejak diumumkannya BTS sebagai brand ambassador LG Mobile terbaru, masyarakat memperlihatkan minat dan perhatian yang sangat luar biasa kepada brand LG Hal tersebut dibuktikan dengan meningkatnya pengikut di akun Twitter resmi LG dan cuitan di twitter terkait pengumuman itu pun memperoleh lebih dari 66 ribu penyuka dan 39 ribu retweet.

c. Peran BTS dalam membangun brand awareness

Menurut Aaker dalam Priansa (2017:254), menyatakan bahwa brand awareness (kesadaran merek) berhubungan dengan kemampuan konsumen untuk mengenali atau mengingat kembali suatu merek merupakan bagian dalam suatu kategori produk. Kesadaran merek terdiri atas beberapa tingkatan, yang dimulai dari posisi yang paling atas hingga yang paling rendah, yaitu yang pertama adalah unaware brand (tidak menyadari merek), kedua brand recognition (pengenalan merek), brand recall (pengingatan kembali terhadap merek), top-of-mind (puncak pikiran). Brand awareness merupakan hal yang penting bagi sebuah brand, dan juga merupakan tahap awal dari suatu proses pembelian.

Dari hasil wawancara yang dilakukan oleh penulis, beberapa penggemar yang diwawancarai mengatakan bahwa BTS berperan dalam membangun awareness, BTS membuat mereka lebih mengingat LG. Sedangkan ada juga dari mereka yang mengatakan bahwa BTS tidak berperan dalam membangun brand awareness, bagi mereka LG sendiri bukan merupakan merek yang asing, LG sendiri sudah dikenal sebelum BTS menjadi brand ambassador dari LG ini.

Penggemar BTS tidak menyebutkan LG sebagai pilihan pertama mereka dalam smartphone, melainkan menyebutkan merek smartphone lain. Tetapi ketika ditanya apakah mengetahui brand LG, mereka semua menjawab bahwa mereka tahu akan brand LG. Sehingga dapat dikatakan bahwa beberapa penggemar BTS mengetahui brand LG dan menjadi lebih aware setelah BTS menjadi brand ambassador LG, menunjukkan interest terhadap LG tetapi belum mencapai tahap top-of-mind, pilihan pertama mereka.

\section{Simpulan}

Berdasarkan data yang telah berhasil dikumpulkan oleh penulis, maka dapat disimpulkan diantaranya, penggemar BTS berpendapat bahwa BTS berperan dalam membangun brand awareness akan brand LG. Tetapi ada beberapa dari mereka yang mengatakan bahwa sebelum BTS menjadi brand ambassador LG, LG pun bukan brand yang asing bagi mereka. Para penggemar BTS juga mengatakan bahwa mereka lebih aware akan brand LG setelah BTS menjadi brand ambassador LG, tetapi tingkat awareness mereka belum sampai pada tahap top-of-mind, dimana LG menjadi pilihan pertama mereka untuk smartphone. BTS memiliki kecocokan, kredibilitas, dan karisma sebagai brand ambassador LG.

Penggunaan BTS yang sedang naik daun sebagai brand ambassador LG ini merupakan pilihan yang tepat menciptakan respon yang positif, yaitu membuat penggemar BTS lebih aware terhadap smartphone LG G7 ThinQ ini. Penggunaan Youtube sebagai sarana beriklan merupakan pilihan yang tepat karena banyak 
penggemar BTS yang berasal dari generasi millennials. Dari iklan Youtube ini banyak penggemar BTS yang aware akan iklan dan brand LG ini.

\section{Ucapan Terima Kasih}

Penulis ingin mengucapkan banyak terima kasih kepada seluruh narasumber, yaitu para penggemar boygroup BTS, Pak Ryan Tirta dan Bu Dya Loretta yang telah meluangkan waktu dan bersedia untuk diwawancarai dan memberikan informasi yang dibutuhkan penulis selama proses pengumpulan data dalam penelitian ini. Penulis juga ingin mengucapkan terima kasih kepada seluruh pihak yang bersangkutan dalam penelitian ini serta keluarga besar Fakultas Ilmu Komunikasi Universitas Tarumanagara.

\section{Daftar Pustaka}

Basrowi dan Suwandi. (2008). Memahami Penelitian Kualitatif. Jakarta: PT Rineka Cipta

Emzir. (2016). Metodologi Penelitian Kualitatif: Analisis Data. Jakarta: PT Raja Grafindo Persada

LG.com. (2018). Lg Signs International K-Pop Sensation BTS As Global Mobile Ambassadors. <https://www.lg.com/ph/press-release/lg-signs-international-kpop-sensation-bts-as-global-mobile-ambassadors>, diunduh tanggal 20 September 2018)

Moleong, Lexy J. (2012). Metodologi Penelitian Kualitatif. Bandung: PT Remaja Rosdakarya

Morissan, (2010). Periklanan Komunikasi Pemasaran Terpadu, Jakarta: Kencana Prenadamedia Group

Nazir. (2011). Metode Penelitian. Bogor: Penerbit Ghalia Indonesia

Priansa, Donni Juni. 2017. Komunikasi Pemasaran Terpadu Pada Era Media Sosial. Jakarta: CV. Pustaka Setia

Putra, M. I. (2014). Pengaruh Brand Ambassador Terhadap Brand Image Serta Dampaknya Terhadap Keputusan Pembelian (Survey Pada Pengguna Line Di Asia). Jurnal Administrasi Bisnis, 12(1). <http://administrasibisnis.studentjournal.ub.ac.id/index.php/jab/article/view/4 97. $>$ diunduh tanggal 3 Oktober 2018.

Wowkeren.com. (2018). Simak Penuturan Pihak Brand Ternama Ini Atas Meningkatnya Popularitas Produk Mereka Berkat BTS. <https://www.wowkeren.com/berita/tampil/00203199.html > diunduh pada 3 Desember 2018) 